\title{
The Relationship between Some Inflammatory Proteins and Autoantibodies in Diabetic Type II Patients
}

\author{
Asmaa M. Salih ${ }^{* 1}$, Aysar E. Mohamood ${ }^{* *}$, Alia E. M. Al-Ubaidi ${ }^{* * *}$ and \\ Adnan Hadi Jawad*****
}

*Department of Biology, College of Science for Women, University of Baghdad, Baghdad-Iraq.

** Institute of Medical Technology, Al-Mansour, Foundation of Technical Education, Baghdad-Iraq.

*** Department of Biology, College of Science, Al-Mustansyriah University, Baghdad-Iraq.

${ }^{* * * *}$ Central Public Health Lab, Immunology Section, Ministry of Health, Baghdad-Iraq.

1E-mail: asmaa197163@Yahoo.com.

\begin{abstract}
Diabetes mellitus type II considers as inflammatory disease, which it associated with increasing level of sensitive inflammatory proteins, Adult patients with DM type II may progress a slowly failure of Beta-cells. Some patients show an autoimmune nature of the disease, our Present study aimed toevaluatethe relationship between autoantibodies which includes islet cell antibodies and insulin autoantibodies along with some inflammatory sensitive proteins like Ceruleplasminand Transferrinin type II diabetes mellitus of recent onset disease in an Iraqi population. A total of 50 patients with type II diabetes mellitus were studied as well as 31 control healthy individuals, the individuals in each group were divided into sub groups according to the presence of autoantibodies. The present study tested the presence of both autoantibodies against islet cells in both patients and control groups, the results show the presence of at least one type of autoantibodies and the coexistence of two types of autoantibodies where observed in three patients, therefore, the individuals in each group were divided into sub groups according to the presence of autoantibodies. Serum Ceruloplasmin level showed significant increasing between negative patients group and negative control group, but this increasing is non-significant between positive patients group and positive control group. Positive control group showed significant increasing in serum Ceruloplasmin level compared to negative control group and thatincreasing made serum Ceruloplasmin level in positive control group closely related to its level in positive patient group, while positive patient group showednon- significant increasing compare to negative patient group. Transferrin showed non-significant decreasing level in patient group compared with control for both groups of autoantibody. Present results may refer to inflammatory aspects of disease which associated with autoimmunity markers, moreover, the presence of autoantibodies increased the serum Ceruloplasmin level and decreased level of Transferrin even in healthy individuals. Present conclusion could help in the diagnosis and provide protection from developing disease.
\end{abstract}

Keywords: Sensitive inflammatory protein, Ceruloplasmin, Transferrin, autoantibody, islet cell antibodies, insulin autoantibodies, diabetes mellitus.

\section{Introduction}

Diabetes mellitus [DM] type II is a disease associated with various metabolic disorders, the main feature of which is chronic hyperglycemia due to fail of Pancreatic ßetacells to meet the increased secretory demand of insulin which it caused by insulin resistance [1].DM type II is common disease affected over 124 million individuals wide world, most of them are usually old when the disease was diagnosed, many of them over the age of 40 years [2]. Diabetes mellitus is considered as inflammatory disease implicating chronic subclinical inflammation as a factor in the pathophysiology of diabetes [3].Chronic elevated glucose level in DM increases inflammatory markers that could help in predicting type II diabetes, particularly for high risk populations [4].

Inflammation is associated with increasing level of sensitive inflammatory proteins [SIPs] [1]. Increased level of [SIPs] were found in patients with DM type II [5]. Ceruloplasmin $[\mathrm{Cp}]$ is synthesized mainly in hepatocytes as glycoprotein with six atoms of copper incorporated prior to secretion and secreting into the plasma [6,7].Although it is exerted as copper transporter, $\mathrm{Cp}$ may increase in serum 
protein type II diabetes [8]. Therefore it is necessary to clarify the effect of serum $\mathrm{Cp}$ level in DM patients. Transferrin $[\mathrm{TF}]$ is a single polypeptide chain with carbohydrate moieties in the c-terminal and two homologous domains each containing an iron binding site [9]. It is synthesized almost exclusively in the hepatocytes, with lesser amount in choroids plexus of the brain [6], then transporting iron through the blood to the liver and bone marrow. The gene for $\mathrm{TF}$ is in chromosome band $3 q 21$ [9].

The autoimmune antibody against islet cell antibodies in diabetic typeI can cause $\beta$ etacells lesion and destruction which leads to insulin deficiency like autoantibodies to islet cell cytoplasm [ICA][10]. The absence of markers or manifestations of type I diabetes is often taken as indicating type II diabetes, because there are no reliable markers for type II diabetes. Adult patients with DM type II may progress a slowly failure of Beta-cells [11]. Some patients show an autoimmune nature of the disease, these patients showed a positive test for pancreatic autoantibodies like antibodies direct against cell islet antigen [ICA]. A previous study of $\beta$-cells function showed that only ICA mostly develop $\beta$-cells failure after five years even though it may take up to 12 years until $\beta$-cells failure occurs in some patients, impairment in the $\beta$-cells response to intravenous glucose and glucagon could be used to diagnosis of diabetes [10]. While another report showed that autoantibodies need only three years to destroy $\beta$-cells [11].

The present study aims to evaluate thePresence of autoantibodies ICA, Insulin autoantibody [IAA] and some sensitive inflammatory protein in the serum with the relationship between autoantibody against islet cell,Ceruloplasmin and Transferrin to clarify their role in the pathogenesis of type II diabetes in elderly Iraqi patients.

\section{Materials and Methods}

\section{1-Sample collection:}

Fifty patients with previous diagnosed diabetes mellitus type II were examined by the physicians in Ibn Al-Nafis Teaching hospital from march 2009 to Sep. 2009. Patients with a history of chronic inflammatory disease, smokers, alcoholics and women with hormonal treatment were excluded in this study.A group consists of thirty one healthy Iraqi individuals with age, sex and ethnic matching were considered as control group. Patients group was with age range [40-79]. Control group was with age range [38-62].

All for both patients and control groups were divided into major groups according to the presence of autoantibodies (group included the 3-The laboratory examination for:

presence of autoantibodies which is called positive group and other group included individuals with non-presence of autoantibodies which is called negative groups). At the same time, for study the age prevalence these major groups were subdivided into minor groups according to the type of autoantibodies,so there are seven subgroups, two negativegroups for autoantibodies (patients and control),two positivegroups for ICA (patients and control),onepositivegroup for IAA (only patients because in our study no healthy individual had IAA autoantibodies) and two groups for coexistence of two types autoantibodies (patients and control)since three patients had concomitant autoantibodies and only one healthy individual.

\section{2- The laboratory examination for Sensitive inflammatory proteins:}

Sensitive inflammatory proteins (SIPs), both of serum ceruloplasmin and transferrin levels where estimated by signal radial immunodiffusion(SRID) plates for accurate quantitative determination of proteins in human serum (Biomaghreb, Tunisia), Using specific endplate, with incubation for $48 \mathrm{hr}$. at $23 \mathrm{C}^{\circ}$ in case of $\mathrm{Cp}$ and $\mathrm{TF}$ the concentration of $\mathrm{Cp}$ and $\mathrm{TF}$ were determined from the standard curve (reference $\mathrm{Cp}$ and $\mathrm{TF}$ concentration, versus square of ring diameter)and expressed as:

Normal value for $\mathrm{Cpg} / \mathrm{L}\{0.19-0.57\}$

Normal value for $\mathrm{TF} g / \mathrm{L}\{2.1-4.3\}$.

\section{3-The laboratory examination for:}

Autoantibodies includes: Islet cell antibody test (ICA) and Insulin autoantibody, both of them were estimated by the indirect immunofluoescence technique (I.I.F) by kit (Euroimmune, Germany) as the following steps: 
1. Frozen sections of Monkey pancreas were incubated with diluted patients serum sample.

2. The circulating autoantibody in the serum will binding with specific tissue antigens in sections then form stable antigen - antibody complex in the presence of specific antibodies.

3. Washing the sections.

4. The substrate will be incubated with fluorescein conjugated anti-human globulin reagent and made visible with fluorescence microscope.

5. The staining will show slightly stain background with positive ICA result, while it will show bright with positive IAA result.

\section{4-Statistical analysis:}

The data analysis were performed using statistical package for Social Science (SPSS) version 7.5. Data were analyzed for mean and standard deviation. Significant tests were done with the student t-test and Duncan test. The result was considered significant at $\mathrm{P} \leq 0.05$.

\section{Results}

\section{1- Demographic data:}

The age prevalence of the patient group with negative presence of autoantibody were higher significantly $(\mathrm{P} \leq 0.05)$ than the negative control, while that increasing was non-significant compared to control group with positive ICA. All patient groups with positive result for autoantibody were higher significantly $(\mathrm{P} \leq 0.05)$ in age than the patients with negative presence of autoantibody, while all patient groups with positive Presence of autoantibody were non-Significantly different compared to control group with positive ICA and IAA. Furthermore, there are significant differences between each one of control groups with one healthy individual had concomitant auto antibodies [Table (1)].
Table (1)

Distribution of study subjects with their age.

\begin{tabular}{|c|c|c|c|c|}
\hline \multicolumn{2}{|c|}{ Groups } & No. & $M e a n \pm S D$ & Dunc- \\
\hline \multirow{4}{*}{ Patients } & $\begin{array}{l}\text { with negative } \\
\text { autoantibody }\end{array}$ & 34 & $52.68 \pm 10.81$ & $\mathrm{~b}$ \\
\hline & $\begin{array}{c}\text { with } \\
\text { positive } \\
\text { ICA }\end{array}$ & 11 & $61.18 \pm 14.47$ & a \\
\hline & $\begin{array}{c}\text { with } \\
\text { positive IAA }\end{array}$ & 5 & $69.0 \pm 8.92$ & $\mathrm{a}$ \\
\hline & $\begin{array}{l}\text { with positive } \\
\text { ICA and IAA }\end{array}$ & 3 & $73.33 \pm 5.69$ & a \\
\hline \multirow{3}{*}{ Control } & $\begin{array}{l}\text { with negative } \\
\text { autoantibody }\end{array}$ & 26 & $46.19 \pm 7.41$ & $\mathrm{c}$ \\
\hline & $\begin{array}{l}\text { with positive } \\
\text { ICA }\end{array}$ & 4 & $49.25 \pm 8.77$ & $\mathrm{~b}$ \\
\hline & $\begin{array}{l}\text { with positive } \\
\text { ICA and IAA }\end{array}$ & 1 & 62 & $\mathrm{a}$ \\
\hline
\end{tabular}

* The different letters mean Significant differences $\boldsymbol{P} \leq 0.05$

2- Ceruloplasmin levels:

The serum level of Ceruloplasmin in Patient group were higher significantly $(\mathrm{P} \leq 0.01)$ than the control with negative presence of auto antibodies, while patient group were higher non-significantly $(\mathrm{P} \leq 0.244)$ than the control for positive presence of auto antibodies. Moreover, positive control groups were higher significantly $(\mathrm{P} \leq 0.040)$ than the negative control groups, while positive patient groups were non- significantly differences $(\mathrm{P} \leq 0.415)$ than the negative patient groups in serum Cp level [Table (2)].

Table (2)

Statistical analysis among study groups according to the concentration of Ceruloplasmin $(\mathrm{g} / \mathrm{L})$ and the presence of auto antibodies.

\begin{tabular}{|c|c|c|c|c|c|}
\hline \multirow{2}{*}{$\begin{array}{c}\text { Autoantibodies } \\
\text { Presence }\end{array}$} & \multicolumn{2}{|c|}{$\begin{array}{c}\text { Patient } \\
\text { group }\end{array}$} & \multicolumn{2}{|c|}{$\begin{array}{c}\text { Control } \\
\text { group }\end{array}$} & \multirow{2}{*}{$\begin{array}{c}P \text { - } \\
\text { value }\end{array}$} \\
\hline & No. & $\begin{array}{c}\text { Mean } \\
\pm S D\end{array}$ & No. & $\begin{array}{c}\text { Mean } \\
\pm S D\end{array}$ & \\
\hline Negative group & 37 & $\begin{array}{c}0.439 \\
\pm \\
0.014\end{array}$ & 26 & $\begin{array}{c}0.375 \\
\pm \\
0.062\end{array}$ & $0.001 *$ \\
\hline Positive group & 13 & $\begin{array}{c}0.462 \\
\pm \\
0.089\end{array}$ & 5 & $\begin{array}{c}0.426 \\
\pm \\
0.038\end{array}$ & 0.244 \\
\hline P-value & & 0.415 & & $\begin{array}{c}0.040 \\
*\end{array}$ & $\mathrm{P} \leq 0.05$ \\
\hline
\end{tabular}

*Significant differences $P \leq 0.05$. 
3-Transferrin level:

The serum level of Transferrin in Patient groups were lower non-significantly $(\mathrm{P} \leq 0.481), \quad(\mathrm{P} \leq 0.652)$ than the control for negative and positive presence of autoantibody consequently, moreover there were nonsignificant differences within main groups [Table (3)].

Table (3)

Statistical analysis among study groups according to the concentration of Transferrin $(\mathrm{g} / \mathrm{L})$ and the presence of autoantibody.

\begin{tabular}{|c||c||c||c||c||c||}
\hline \multirow{2}{*}{$\begin{array}{c}\text { Autoantibody } \\
\text { Presence }\end{array}$} & \multicolumn{2}{|c||}{ Patient group } & \multicolumn{2}{c||}{ Control group } & \multirow{2}{*}{ P-value } \\
\cline { 2 - 6 } & No. & Mean \pm SD & No. & Mean \pm SD & \\
\hline \hline negative group & 37 & $3.325 \pm 0.719$ & 26 & $3.455 \pm 0.709$ & 0.481 \\
\hline \hline Positive group & 13 & $3.004 \pm 0.841$ & 5 & $3.400 \pm 1.700$ & 0.652 \\
\hline \hline P-value & & 0.242 & & 0.217 & $\mathrm{P} \leq 0.05$ \\
\hline
\end{tabular}

*Significant differences $\mathbf{P} \leq 0.05$.

\section{Discussion}

Present study agreed with previous report that recorded prevalence of ICA auto antibodies in the serum of Iraqi diabetic patients [12], and ICA with IAA in Iraqi patients with DM II [13]. Present study recorded a positive presence of two types of auto antibodies for both patients and control that may relate with aging process of the immune system which may lead to increase the frequency of auto antibodies occurrence [14], we can explain it is related with aging especially when coexistence of two auto antibodies appear in patient with highly mean age $(73.33 \pm 5.69)$ or may be related with insulin treatment since insulin treatment can stimulate IAA production [10]. A fellow up study recorded presence of ICA in serum of patients with DM type II, those patients will progressively decreesebeta-cells function after diagnosis within three years, whereas betacells function in type II diabetic patients without ICA unchanged [11]. In our present data, the presence of positive ICA is higher than IAA that agreed with recent study that had demonstrated that the presence of positive ICA was much more than the presence of positive IAA in adult patients of DM [10].

Moreover, present review showed that coexisting of two types auto antibodies at the same patients, that could be reasonable for Iraqi patients and agree with other reports about other population because approximately $10 \%$ of phenotypic type II diabetic patients are positive for at least one of the islet auto antibodies [10].Furthermore, coexisting of two types auto antibodies at the same patients means these patients of type II diabetes will progress disease complication more rapidly [10], or the progression to insulin dependence is believed to be more rapid than in patients with antibody negative result [12], the rate of progression disease in individuals younger than 45 years of age was remarkably similar to that of first degree relatives of type I diabetic [15].

Present data disagree with a previous study which recorded a significant decreasing of serum $\mathrm{Cp}$ in DM type II patients [2]. In contrast, the present study showed significant increasing serum $\mathrm{Cp}$ level in both groups of patient with diabetic type II, this result supports previous finding that hyperglycemia could be a cause of increasing serum Cp level in DM patients $[7,8,16]$.This increase of $\mathrm{Cp}$ may be related to the role of inflammatory sensitive protein which synthesis by hepatocytes in response to tissue damage and inflammation $[4,6]$, at the same time, Cpis an important intravascular antioxidant factor and it protects tunica in tima against free radical injury [6].In addition, the function of $\mathrm{Cp}$ as a scavenger, may be related to the increasing serum $C p$ level in a patient of diabetes mellitus

$[8,17]$. An increased level of $\mathrm{Cp}$ may associate with other risk factors when they observed generally higher $\mathrm{Cp}$ Level in smokers serum compared with non-smokers patients with DM type II [6, 18, 19]. Moreover, elevated level of $\mathrm{Cp}$ could be a risk and predict factor for the complication which will associate with diabetic type II [20]. At the 
same time, positive control group of autoantibody showed significant increase in $\mathrm{Cp}$ level compared with negative control group that may relate with destruction effect of autoantibody and autoantibody will enhance consuming of sensitive inflammatory protein $[3,11]$, besides it may be related with $\mathrm{Cp}$ gene defect because the gene defect may influence the population of islet cells since Pancreas cells revealed a marking reduction in insulincontaining cells in the islets [21].

Present review showed that nonsignificant decreasing in Transferrin level compared to control for both groups of presence autoantibody. This result disagreed with previous report which showed that significant decreasing in TF level [6], that may be related with the antioxidant deficiency and excessive peroxide -mediated damage may appear in non-insulin dependent DM[22], which in turn associated with an increase serum $\mathrm{Cp}$ level as oxidant scavenger so $\mathrm{Cp}$ serves as a peroxidase that converts toxic ferrous iron to non-toxic ferric iron, which thereby becomes available for binding to and transport by $\mathrm{TF}[23]$.An increased oxidant stress has been implicated in the pathogenesis of DM, which will activate inflammatory cell to release a large amount of inflammation sensitive protein like $\mathrm{Cp}$ [7], increasing oxidant stress may consume significant quantities of $\mathrm{TF}$ that may explain an increasing $\mathrm{Cp}$ level and decreasing $\mathrm{TF}$ level in present data, because increasing $\mathrm{Cp}$ permits the incorporation of iron into $\mathrm{TF}$ [18], that iron release from storage site since hyperglycemia may lead to increase availability of transition metals ions[2].Moreover oxidant stress may associate with increasing production of free radicals or may possibly indicate increasing of glycation of proteins that may damage antioxidant proteins [6].All these conditions must be tightly regulated by proteins that transport, sequester, and mobilize iron from stores and $\mathrm{Cp}$ is a highly effective antioxidant that can prevent oxidative damage to lipids, DNA and protein[2,18,22].

Present data showed that the coexistence of $\mathrm{Cp}$ and IAA in study groups, both markers may associate with aging, since serum $\mathrm{Cp}$ level increases with aging in normal individual [7]. Insulin also has been regulate $\mathrm{Cp}$ expression then $\mathrm{Cp}$ gene expression related to the aging and diet [23], besides auto antibodies could be a marker of subliminal auto aggression process against beta-cells, which is caused by aging or of the instability of the immunological system related to aging or both [19]. In contrast other study mentioned that auto antibodies were detected in DM II patients with no markers of activation of the inflammatory proteins [10].

\section{Conclusion}

1- The present study emphasized the need for a long-term follow-up of patients with DM type II, also a prospective cohort studies required to clarify the clinical relevance of SIPs serum levels in DM patient and the relation between SIPs, and auto antibodies because present data had indicated a proportion among them.

2- We need more specific studies focusing on genetic predisposing of DM type II.

\section{Acknowledgement}

We wish to express our appreciation to Dr. Ali Husain Idhaia, College of Science, Baghdad University for revising this paper.

\section{References}

[1] Seino Y.Nanjo K. Tajima N. Kadowaki T. and Ueki K. "Report of the Committee on the classification and diagnostic criteria of diabetes mellitus". Diabetol Int.1, 2-20, 2010.

[2] Sarker A. Dash S. Barik B. Muttigi M. Kedage V. Shetty J. and Prakash M. "Copper and Ceruloplasmin levels in relation to total Thiols and GST in type II Diabetes Mellitus patients". Ind J ClinBiochem. 25(1), 74-76, 2010.

[3] Pickup J. "Inflammation and activated innate immunity in the pathogenesis of type II diabetes". Diabetes Care.27, 813-823, 2004.

[4] Abou-Shouhas S. AdbEi-Mageed M. and Sultan H."Interleukin-8, ferritin and soluble transferring receptors in type II Diabetes Mellitus". Egypt j Immuno 1.13(1), 19-25, 2006.

[5] Shamin S. D'Souza V. and Manjrekar P. "Acute Phase Protiens in newly diagnosed diabetics". Biomedical Research. 19 (1), 4953, 2008. 
[6] Mermisogullari R. and EbubekirB."Levels of Ceruloplasmin, Transferrin and Lipid peroxidation in the serum of patients with type II diabetes mellitus" J. diabetes compli. 18(4),193-197,2004.

[7] Daimon M. Susa S. Hasegawa K. Yamaguchi $H$. Kimura M. Ohnuma $H$. Eguchi h. and Kato T. "Increase in serum Ceruloplasmin with aging is not observed in type II diabetes". Endocrine J.47 (3), 215219, 2004.

[8] Hajime U. Kumika T. and Yukitaka M. "Examination of Ceruloplasmin in type II diabetes mellitus" Japanese J ClinExper Med.77 (11), 2123-2124, 2000

[9] Yonekawa M. Okabe T. Asamoto Y. and Ohta M. "A case of heredity Ceruloplasmun deficiency with iron deposition in the brain associated Chorea, Dementia, Diabetes mellitus and Retinal pigmentation: administration of fresh -frozen human plasma" Eur Neurol.42, 157-162, 1999

[10] Ramachandra N. Books B. and Palmer J. "Latent autoimmune diabetes in adults" J. ClinEndocrinMetabol.94 (12), 4635-4644, 2010.

[11] Gostter A. Landin-Olsson M. Fernula A. and Sundkvist G. "Beta-Cell function in relation to islet cell antibodies during the first 3 Yr after clinical diagnosis of diabetes in type II diabetic patients" Diabetes care.16 (6), 902-910, 1993.

[12] Kurowska M. Tarach S. Malica J. an "dJanoeska H." Insulin autoantibodies (IAA) in elderly patients with type II diabetes". AnnalesUMCS, Pharmacia. 21(1), 327-331, 2008.

[13] Salih, Asmaa M. "Study some inflammatory proteins and autoantibodies in elderly Iraqi patients with Diabetic Mellitus type II" 23(1) AL-Mustansiriyah $\mathrm{j}$ of Science( accepted for published ).2012.

[14] Umpaichitra V. Baneerji M. and Castells S." Autoantibodies in children with type II diabetes mellitus" jpediatr Endocrinol Metab. 15(1):525-30. 2002.

[15] Pietropaolo M. Mitchell E. and Kuiier L. "The Heterogeneity of Diabetes" Diabetes.56, 1189-1197, 2007.
[16] Daimon M. Susa S. Yamamata K. Yamaguchi H. Hama k. Ohnuma H. and Kato T. "Hyperglycemia is a factor for an increase in serum ceruloplasmin in type II diabetes". Diabetes care. 21 (9), 1525-1528, 1998.

[17] Chacko S. and Cheluvappa R."Increased ceruloplasmin and fibrinogen in type II diabetes correspondes to decreased puantioxideant activity in a preliminary tertiary South Indian hospital study" Exp Clin Endocrine Diabetes,118(1), 64-67, 2010

[18] Mabayoje V. Akanni E. Arinola G. and Hassan R. "Plasma Transferrin and Ceruloplasmin levels in Nigerian with Diabetes mellitus. Inter J Tropic Med.5 (1), 6-9, 2010.

[19] Virgolici B. Mohora M. Gaman L. Alixandru D. Manolescu B. andStoian I. "Relation between inflammation and oxidative stress markers in Diabetic Foot Patients" Romanian J. Biophys.18 (4), 273282, 2008.

[20] Mermisogullari R. Tays S. Ebubekir B.and Capoglu I."Antioxidant status and lipid peroxidation in type II diabetes mellitus" Cell Biology and function.21 (3), 291-296, 2003.

[21] Kato T. Daimon M. Kawanami T. Ikezawa Y. and Maede K." Islet changes in hereditary Ceruloplasmin deficiency". Human Pathology. 28(4), 499-502, 1997.

[22] Jasem M. Al-ubaidi A. Admon A. and Zwaer K."Prevalence of LADA among clinical diagnosed type II diabetic patients" Medical j. of Islamic World Academy of Sciences.18 (2), 49-54, 2010.

[23] Wiggins J. Goyal M. Wharram B. and Wiggins R. "Antioxidant Ceruloplasmin is expressed by glomerular pariental epithelial cells and secreted into urine is associated with glomerular aging and highcalorie diet". J Am SocNephrol. 17, 13821387, 2006. 


\section{الخلاصة}

مرض السكري من النوع الثاني يعد من الامراض

الالتهابية والتي نرتبط بزيادة مستوى البروتينات الالتهابية

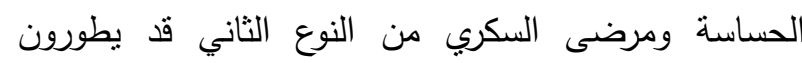

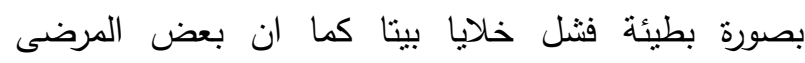

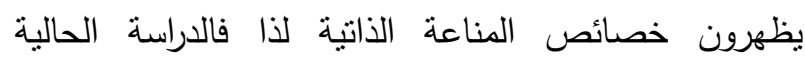
صممت لتقييم وجود بضع دلائل منل الاجسام المضادة

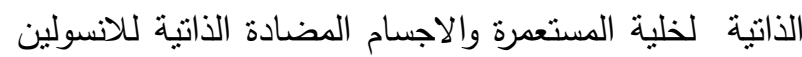
وعلاقتها ببعض البروتينات الالتهابية مثل السيريلوبلازمين

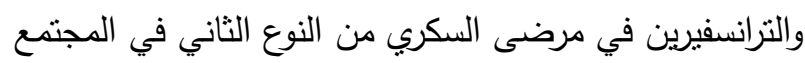

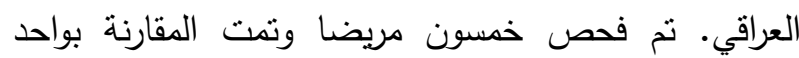
وثلاثثين فردا من الاصحاء وقسم افراد الدراسة الى مجاميع ثانوية حسب نتيجة الفحص لوجود الاضداد الذاتية, واضهرت

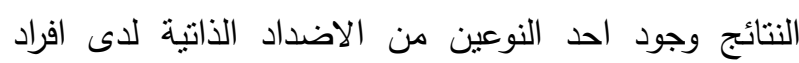

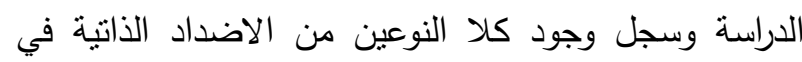
ثلاثة من المرضى واحد الافراد الاصحاء كما اضهرت

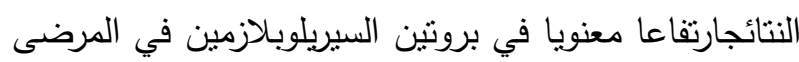

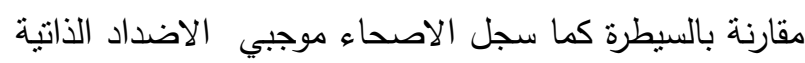
ارتفاعا معنويا في مستوى بروتين السيريلوبلازمين المصلي بلي الاهي

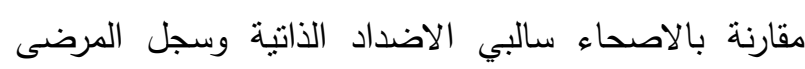

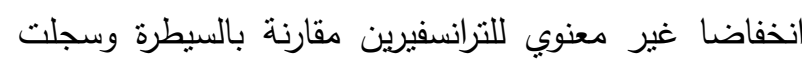
السبطرة نسبة موجبة لوجود الاضداد الذاتية كلاهما ترافقت

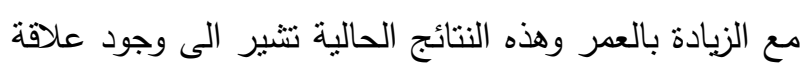

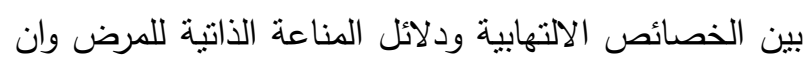
وجود الاضداد الذاتية قد يرتبط بارتفاع مستوى بروتين

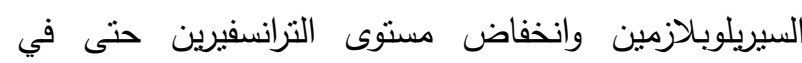
الافراد الاصحاء وكأستتناج نهائي نساعد الدراسة الحالية في التتخيص والوقاية من تطور المرض. 